\title{
The effect of tetraploid Robinia pseudoacacia leaf meal on performance, egg quality, and nutrient digestibility in laying hens
}

\author{
G.J. Zhang ${ }^{1,2}$, Y. Li ${ }^{1,4}$, Y.H. Sun 1 , C.Q. Yuan ${ }^{1}$ and Z.H. Xu1 ${ }^{1,3}$ \\ ${ }^{1}$ Beijing Forestry University, National Engineering Laboratory for Tree Breeding, College of Biological Sciences and Biotechnology \\ Beijing 100083, P.R. China \\ ${ }^{2}$ Hebei Normal University of Science and Technology, College of Horticulture Science and Technology \\ Qinhuangdao 066600, P.R. China \\ ${ }^{3}$ Beijing Forestry University, College of Forestry, Beijing 100083, P.R. China
}

KEY WORDS: tetraploid Robinia pseudoacacia, laying hen, egg quality, performance, digestibility

Received: 07 November 2012

Revised: 21 August 2013

Accepted: 12 November 2013

${ }^{4}$ Corresponding author: e-mail: yunli@bjfu.edu.cn
ABSTRACT. A 60-day feeding experiment was conducted to study the effects of including $0,20,40$, or $60 \mathrm{~g} \cdot \mathrm{kg}^{-1}$ leaf meal of tetraploid Robinia pseudoacacia (TRLM) in diets on performance, egg quality, and apparent nutrient and amino acid digestibility of hens. Egg mass and egg weight were both higher when feeding $40 \mathrm{~g} \cdot \mathrm{kg}^{-1}$ TRLM than the other three diets, the egg shape index linearly increased $(P<0.05)$. No significant effects of diet were seen on the other hen performance or egg quality parameters. Apparent nutrient and amino acid digestibilities increased at first and subsequently decreased with increasing inclusion of the foliage, but no significant differences were observed in dry matter or glycine. Digestibility of crude protein, ether extract, gross energy and acid detergent fibre increased up to $20 \mathrm{~g} \cdot \mathrm{kg}^{-1}$ TRLM and subsequently decreased, and similar trends were observed for 13 amino acids, but the digestibility of neutral detergent fibre decreased up to $40 \mathrm{~g} \cdot \mathrm{kg}^{-1}$ TRLM and subsequently increased. A significant linear decrease $(P<0.05)$ in the digestibility of proline was observed with increasing inclusion of TRLM into the diets. Tetraploid Robinia pseudoacacia leaf meal could be a potential supplementary protein source in laying hen diets at inclusion levels not exceeding $60 \mathrm{~g} \cdot \mathrm{kg}^{-1}$.

\section{Introduction}

Black locust (Robinia pseudoacacia L.) is a leguminous, deciduous, fast growing tree species native to the southeastern USA. It is a multi-purpose tree species suitable for production of timber, fuel wood, land reclamation, beekeeping, and forage (Barrett et al., 1990). Its use for forage is becoming a prominent practice in China and other parts of the world with a temperate climate owing to the superiority of biomass production and high protein content compared with other woody fodder species (Papanastasis et al., 1997; Ainalis and Tsiouvaras, 1998; Burner et al., 2005).

In addition, Takada et al. (1980) compared lucerne meal and black locust meal at the $50 \mathrm{~g} \cdot \mathrm{kg}^{-1}$ level in poultry diets. There were no differences in body weight or mortality between the two treatments. 
When Cheeke et al. (1983) compared lucerne and black locust at a high $\left(200 \mathrm{~g} \cdot \mathrm{kg}^{-1}\right)$ level in broiler chicken diets, however, they found a pronounced growth depressing effect of black locust, which was partially overcome by autoclaving (indicative of a tannin effect). Therefore, development of low-tannin cultivars, selected for superior feeding responses, would enhance the prospects of black locust as forage.

Tetraploid Robinia pseudoacacia, which was colchicine-induced from black locust (Kim and Lee, 1973), is considered to be a more promising forage tree than diploid R. pseudoacacia (Li et al., 2009). The tannin content in leaves ranged from 10 to $20 \mathrm{~g} \cdot \mathrm{kg}^{-1}$ in tetraploid $R$. pseudoacacia (Zhang et al., 2009) as compared with 65.9 to $104 \mathrm{~g} \cdot \mathrm{kg}^{-1}$ in diploid R. pseudoacacia (Negi et al., 1989; Unruh Snyder et al., 2007). Moreover, the content of crude protein (CP) and 18 amino acids (AA) in tetraploid $R$. pseudoacacia leaves can reach $270 \mathrm{~g} \cdot \mathrm{kg}^{-1}$ and $180 \mathrm{~g} \cdot \mathrm{kg}^{-1}$, respectively, making the tree an excellent fodder for animals (Zhang et al., 2007, 2012). Moreover, no significant differences have been observed among goats fed R. pseudoacacia at 300-600 $\mathrm{g} \cdot \mathrm{kg}^{-1}$ in terms of average daily gain. Neither were there any significant differences in milk yield or milk quality between dairy cows fed $R$. pseudoacacia and lucerne at $100 \mathrm{~g} \cdot \mathrm{kg}^{-1}$ (unpublished report).

There is no information, however, regarding the effect of tetraploid Robinia pseudoacacia leaf meal (TRLM) on monogastric animals. The objective of the present study was to examine the effects of increasing proportions of TRLM in laying hen diets on performance, egg quality, and nutrient and AA digestibility.

\section{Material and methods}

\section{Husbandry and diets}

A total of two thousand 240-day-old Hy-Line Brown laying hens were housed in cages. Sixteen uniform groups of 125 hens each constituted the experimental units. The trial lasted for $60 \mathrm{~d}$ and started after a pre-experimental period of $7 \mathrm{~d}$, during which the birds received the same diet. Diets were fed in mash form. Feed and water were supplied ad libitum. The hens received $15 \mathrm{~h}$ light per day throughout the experiment. Room temperature was also controlled at about $25^{\circ} \mathrm{C}$.

Four replicates were randomly assigned to each of the four dietary treatments, which consisted of $0,20,40$, or $60 \mathrm{~g} \cdot \mathrm{kg}^{-1}$ TRLM. The ingredient and chemical compositions of the TRLM and basal diets are shown in Tables 1 and 2.
Table 1. Chemical composition of tetraploid Robinia pseudocacia leaf meal in early August, $\mathrm{g} \cdot \mathrm{kg}^{-1}$

\begin{tabular}{|c|c|c|c|c|c|}
\hline Nutrient & Content & Nutrient & Content & Nutrient & Content \\
\hline$\overline{\mathrm{DM}}$ & 339.8 & Tannin & 15.2 & Valine & 8.7 \\
\hline $\mathrm{CP}$ & 195.9 & Aspartic acid & 24.3 & Isoleucine & 6.5 \\
\hline EE & 49.5 & Threonine & 6.8 & Leucine & 11.8 \\
\hline CF & 164.4 & Serine & 8.0 & Tyrosine & 5.3 \\
\hline NDF & 471.9 & Glutamic aci & d 13.5 & Phenylalanine & 8.5 \\
\hline ADF & 315.2 & Proline & 12.6 & Histidine & 7.7 \\
\hline Calcium & 10.7 & Glycine & 7.5 & Lysine & 8.4 \\
\hline Phosphorus & 1.6 & Alanine & 8.1 & Arginine & 9.0 \\
\hline
\end{tabular}

$\mathrm{DM}$ - dry matter; $\mathrm{CP}$ - crude protein; $\mathrm{EE}$ - ether extract; $\mathrm{CF}$ - crude fibre; NDF - neutral detergent fibre; ADF - acid detergent fibre

Table 2. Ingredients and nutrient composition of the experimental diets, $\mathrm{g} \cdot \mathrm{kg}^{-1}$ as fed basis

\begin{tabular}{lcccc}
\hline Ingredient & Diet 1 & Diet 2 & Diet 3 & Diet 4 \\
\hline Tetraploid Robinia pseudocacia & 0 & 20 & 40 & 60 \\
leaf meal & 600.0 & 592.5 & 583.9 & 577.9 \\
Maize & 30 & 27 & 25 & 19 \\
Wheat bran & 200 & 192 & 184 & 177 \\
Soyabean meal & 50 & 50 & 50 & 50 \\
Cotton seed meal & 89 & 87 & 85 & 84 \\
Limestone & 14.0 & 14.5 & 15.0 & 15.0 \\
Calcium phosphate dibasic & 3 & 3 & 3 & 3 \\
Salt & 10 & 10 & 10 & 10 \\
Vitamin-mineral premix & 1 & 1 & 1 & 1 \\
Choline (VB ${ }_{4} 500, \mathrm{~g} \cdot \mathrm{kg}^{-1}$ ) & 2 & 2 & 2 & 2 \\
Lysine & 1.0 & 1.0 & 1.1 & 1.1 \\
DL-Methionine & & & & \\
Calculated analysis & 166.4 & 166.4 & 166.4 & 166.4 \\
$\quad$ crude protein & 27.9 & 29.6 & 31.4 & 33.0 \\
crude fibre & 26.8 & 26.7 & 26.6 & 26.5 \\
ether extract & 35.0 & 35.0 & 35.0 & 35.2 \\
calcium & 5.9 & 5.9 & 6.0 & 5.9 \\
phosphorus & 3.6 & 3.6 & 3.7 & 3.6 \\
available phosphorus & 9.50 & 9.50 & 9.51 & 9.52 \\
lysine & 3.63 & 3.63 & 3.65 & 3.61 \\
methionine & 6.61 & 6.55 & 6.42 & 6.33 \\
methionine + cystine & 10.78 & 10.78 & 10.78 & 10.78 \\
metabolizable energy, $\mathrm{MJ}^{-} \cdot \mathrm{kg}^{-1}$ & 1.2 & \\
\hline
\end{tabular}

composition of vitamin-mineral premix provided per kg: IU: vit. A $2,000,000$, vit. D 400,000; vit. E, 4,000; mg: vit. $K_{3} 200$, vit. B 200 , vit. $B_{2} 800$, vit. $B_{6} 200$, vit. $B_{12} 2$, D-calcium pantothenic acid 2000 , niacin 6000 , folic acid 2, biotin 6, iodine 160, selenium 80; g: iron 12, copper 3 , manganese 15 , zinc 16

\section{Performance and egg quality}

Egg production, egg weight, feed consumption and mortality were recorded daily throughout the trial. Twelve eggs per replicate were collected during the last 3 days to determine egg quality traits. Haugh units, yolk colour and albumen height were measured by an egg multitester EMT-5200 (Robotmation, Co., Ltd., Tokyo, Japan). Shell colour and shell thickness were measured by taking the mean of three pieces - from the two ends and from the middle - using a QCR colour reflectometer (Technical Services and Supplies, UK) and a micrometer. 
Egg length and width were measured using a calliper and were recorded in centimetres. Egg shape index was defined as the length-to-width ratio. Shell strength was assessed using an robotmation machine (Model-II, Robotmation, Co., Ltd., Tokyo, Japan) and was recorded in kilograms of force required to crack the shell surface (Hammerle, 1969). The feed conversion ratio was calculated as grams feed consumption per day per hen divided by gram egg mass per day per hen.

\section{Nutrient and AA apparent digestibility}

During the last 3 days, feed intake was monitored, and the excreta were collected daily at $09.00 \mathrm{~h}$. Care was taken to avoid contamination from feathers, scales and debris. Each day, the excreta were frozen with $10 \% \mathrm{H}_{2} \mathrm{SO}_{4} 10 \mathrm{ml}$ per $100 \mathrm{~g}$. For each treatment per replicate, the 3 excreta samples from the 3 days were pooled and dried for $24 \mathrm{~h}$ at $80^{\circ} \mathrm{C}$ in a forced-air oven for analysis. There were altogether 16 excreta samples for the 4 replicates, each of which weighed about $300 \mathrm{~g}$. The dried excreta were allowed to equilibrate to atmospheric conditions before being weighed. The apparent digestibility $\left(\mathrm{g} \cdot \mathrm{g}^{-1}\right)$ of nutrients and AA was calculated according to the equation:

$$
\text { apparent digestibility }=\frac{\text { INT }- \text { FME }}{\text { INT }}
$$

where: INT (g per day) - the intake, FME (g per day) - faecal matter excreted.

\section{Chemical analyses}

Prior to chemical analysis, samples of feed and dried faecal material were ground in a laboratory sample mill and passed through a $0.25 \mathrm{~mm}$ screen. Dry matter (DM ID 934.01), CP (ID 984.13) and ether extract (EE ID 920.39) were subsequently analysed by the procedures of AOAC (2000). Neutral detergent fibre (NDF) and acid detergent fibre (ADF) were determined according to Van Soest et al. (1991) and expressed inclusive of residual ash. The gross energy of diet and the excreta samples was determined using an adiabatic bomb calorimeter (Gallenkamp Autobomb, UK) standardized with benzoic acid. AA concentrations of samples were analysed by an AA analyser (L-8500A, Hitachi, Tokyo, Japan) after acid hydrolysis $(6 \mathrm{~N} \mathrm{HCl}$ for $24 \mathrm{~h}$ at $110^{\circ} \mathrm{C}$ ).

\section{Statistical analysis}

All data were analysed as a randomized complete block design for a fixed effect of diet and random effect of replicate with the following model using the GLM procedure in version 16.0 of SPSS (SPSS Inc., Chicago, IL, USA) as:

$$
Y_{i j}=\mu+R_{i}+D_{j}+\varepsilon_{i j}
$$

where: $Y_{i j}$ - the dependent variable under examination, $\mu$-the general mean, $R_{i}$ - the effect of replicate $i(i=1,2,3,4), D_{j}-$ the effect of $\operatorname{diet} j(j=1,2$, $3,4), \varepsilon_{i j}$ - the residual.

Results are presented as means with SEM (standard error of means). If differences among treatment means were detected by ANOVA, the Duncan multiple range test was applied to separate means. Contrast statements were utilized to test for linear or quadratic dietary effects. A significance level of $P<0.05$ was used during analysis.

\section{Results}

Egg mass was higher $(P<0.05)$ when feeding $40 \mathrm{~g} \cdot \mathrm{kg}^{-1}$ TRLM to laying hens than $0 \mathrm{~g} \cdot \mathrm{kg}^{-1}$ TRLM (Table 3 ). There were no significant effects of diet on laying rate, feed intake, feed conversion, or mortality rate throughout the experimental period. Neither feed intake nor feed conversion was influenced by TRLM supplementation.

Egg weight was higher $(P \leq 0.05)$ in the diet containing $40 \mathrm{~g} \cdot \mathrm{kg}^{-1}$ TRLM compared with the diets containing $20 \mathrm{~g} \cdot \mathrm{kg}^{-1}$ and $60 \mathrm{~g} \cdot \mathrm{kg}^{-1}$ TRLM (Table 4). The egg shape index increased linearly $(P<0.05)$ from 1.28 to 1.32 with increasing TRLM levels. Egg quality parameters such as eggshell colour, eggshell strength, eggshell thickness, albumen height, Haugh unit and yolk colour were not affected, however, by diet.

The apparent digestibility of $\mathrm{CP}, \mathrm{GE}, \mathrm{NDF}$, and ADF was significantly different $(P<0.05)$ among diets, whereas DM and EE were not affected (Table 5). The apparent digestibility of EE first increased with up to $20 \mathrm{~g} \cdot \mathrm{kg}^{-1}$ TRLM and then decreased. Similar trends were found in the apparent digestibility of CP, GE and ADF, while the trend for the apparent digestibility of NDF was the opposite, as it decreased up to $40 \mathrm{~g} \cdot \mathrm{kg}^{-1}$ TRLM and subsequently increased. Feeding $20 \mathrm{~g} \mathrm{~kg}^{-1}$ and $40 \mathrm{~g} \cdot \mathrm{kg}^{-1}$ TRLM to laying hens resulted in higher $(P<0.05)$ apparent digestibility of $\mathrm{CP}$ and ADF as compared with diets containing $0 \mathrm{~g} \cdot \mathrm{kg}^{-1}$ and $60 \mathrm{~g} \cdot \mathrm{kg}^{-1}$ TRLM, while the apparent digestibility of GE exhibited a significantly higher value $(P<0.05)$ in the diet containing $20 \mathrm{~g} \cdot \mathrm{kg}^{-1}$ TRLM than the other three diets.

Except for glycine, the apparent digestibility of all of the other 14 AA was significantly influenced $(P<0.05)$ by the dietary treatments (Table 6). A significant linear decrease $(P<0.05)$ in the apparent digestibility of proline was observed with increasing inclusion 
Table 3. Effect of tetraploid Robinia pseudocacia leaf meal on performance of laying hens at $240 \mathrm{~d}$ of age

\begin{tabular}{|c|c|c|c|c|c|c|c|c|}
\hline \multirow{3}{*}{ Parameter } & \multirow{3}{*}{ Diet 1} & \multirow{3}{*}{ Diet 2} & \multirow{3}{*}{ Diet 3} & \multirow{3}{*}{ Diet 4} & \multirow{3}{*}{ SEM } & \multicolumn{3}{|l|}{ Probability } \\
\hline & & & & & & \multirow{2}{*}{ main effect } & \multicolumn{2}{|c|}{ contrasts } \\
\hline & & & & & & & linear & quadratic \\
\hline Laying rate, $\%$ & 85.80 & 85.74 & 83.83 & 84.32 & 0.76 & 0.229 & 0.094 & 0.727 \\
\hline Egg mass, $g \cdot$ hen $^{-1} d^{-1}$ & $57.2^{\mathrm{b}}$ & $58.0^{\mathrm{ab}}$ & $59.0^{a}$ & $58.2^{\mathrm{ab}}$ & 0.42 & 0.043 & 0.061 & 0.096 \\
\hline Feed intake, $g \cdot$ hen $^{-1} d^{-1}$ & 128.7 & 131.5 & 130.1 & 129.7 & 1.90 & 0.778 & 0.876 & 0.429 \\
\hline Feed conversion, $\mathrm{g} \cdot \mathrm{g}^{-1}$ eggs & 2.63 & 2.65 & 2.64 & 2.64 & 0.02 & 0.935 & 0.703 & 0.802 \\
\hline
\end{tabular}

means within a row with different superscript $(a, b)$ differ significantly, $P<0.05$

Table 4. Effect of tetraploid Robinia pseudocacia leaf meal on egg quality of laying hens at $240 \mathrm{~d}$ of age

\begin{tabular}{|c|c|c|c|c|c|c|c|c|}
\hline \multirow{3}{*}{ Parameter } & \multirow{3}{*}{ Diet 1} & \multirow{3}{*}{ Diet 2} & \multirow{3}{*}{ Diet 3} & \multirow{3}{*}{ Diet 4} & \multirow{3}{*}{ SEM } & \multicolumn{3}{|l|}{ Probability } \\
\hline & & & & & & \multirow{2}{*}{ main effect } & \multicolumn{2}{|c|}{ contrasts } \\
\hline & & & & & & & linear & quadratic \\
\hline Egg weight, g & $60.42^{\mathrm{ab}}$ & $58.35^{b}$ & $61.50^{\mathrm{a}}$ & $58.85^{b}$ & 0.82 & 0.050 & 0.681 & 0.731 \\
\hline Shell colour & 30.20 & 34.06 & 33.85 & 33.79 & 1.38 & 0.213 & 0.119 & 0.187 \\
\hline Shell strength, $\mathrm{kg} \cdot \mathrm{cm}^{-2}$ & 3.933 & 3.984 & 4.338 & 4.102 & 0.184 & 0.453 & 0.323 & 0.455 \\
\hline Shell thickness, $\mathrm{mm}$ & 0.352 & 0.347 & 0.354 & 0.357 & 0.006 & 0.706 & 0.455 & 0.470 \\
\hline Albumen height, mm & 7.36 & 7.20 & 6.76 & 7.10 & 0.18 & 0.180 & 0.157 & 0.197 \\
\hline Haugh units & 85.50 & 85.18 & 81.95 & 84.27 & 1.05 & 0.143 & 0.175 & 0.241 \\
\hline Yolk colour & 7.92 & 7.42 & 7.92 & 7.63 & 0.24 & 0.436 & 0.739 & 0.679 \\
\hline Egg shape index & 1.28 & 1.30 & 1.31 & 1.32 & 0.01 & 0.194 & 0.045 & 0.716 \\
\hline
\end{tabular}

means within a row with different superscript $(a, b)$ differ significantly, $P<0.05$

Table 5. Effect of tetraploid Robinia pseudocacia leaf meal on apparent nutrient digestibility of laying hens at $240 \mathrm{~d}$ of age, $\mathrm{g} \cdot \mathrm{g}^{-1}$

\begin{tabular}{|c|c|c|c|c|c|c|c|c|}
\hline \multirow{3}{*}{ Nutrient } & \multirow{3}{*}{ Diet 1} & \multirow{3}{*}{ Diet 2} & \multirow{3}{*}{ Diet 3} & \multirow{3}{*}{ Diet 4} & \multirow{3}{*}{ SEM } & \multicolumn{3}{|c|}{ Probability } \\
\hline & & & & & & \multirow{2}{*}{$\begin{array}{l}\text { main } \\
\text { effect }\end{array}$} & \multicolumn{2}{|c|}{ contrasts } \\
\hline & & & & & & & linear & quadratic \\
\hline$\overline{\mathrm{DM}}$ & 0.697 & 0.720 & 0.687 & 0.681 & 0.010 & 0.104 & 0.118 & 0.192 \\
\hline $\mathrm{CP}$ & $0.431^{b}$ & $0.626^{a}$ & $0.565^{\mathrm{a}}$ & $0.449^{b}$ & 0.028 & 0.002 & 0.956 & $<0.001$ \\
\hline EE & 0.619 & 0.713 & 0.656 & 0.579 & 0.037 & 0.141 & 0.310 & 0.048 \\
\hline GE & $0.736^{b}$ & $0.768^{a}$ & $0.732^{b}$ & $0.716^{b}$ & 0.008 & 0.005 & 0.017 & 0.010 \\
\hline NDF & $0.668^{a}$ & $0.625^{\mathrm{a}}$ & $0.529^{b}$ & $0.620^{a}$ & 0.018 & 0.003 & 0.015 & 0.005 \\
\hline ADF & $0.446^{b}$ & $0.661^{\mathrm{a}}$ & $0.652^{\mathrm{a}}$ & $0.449^{b}$ & 0.023 & $<0.001$ & 0.997 & $<0.001$ \\
\hline
\end{tabular}

means within a row with different superscript $(a, b)$ differ significantly, $P<0.05$; DM - dry matter; $C P$ - crude protein; EE - ether extract; GE - gross energy; NDF - neutral detergent fibre; ADF - acid detergent fibre

Table 6. Effect of tetraploid Robinia pseudocacia leaf on apparent amino acid digestibility of laying hens at $240 \mathrm{~d}$ of age, $\mathrm{g} \cdot \mathrm{g}^{-1}$

\begin{tabular}{|c|c|c|c|c|c|c|c|c|}
\hline \multirow{3}{*}{ Amino acid } & \multirow{3}{*}{ Diet 1} & \multirow{3}{*}{ Diet 2} & \multirow{3}{*}{ Diet 3} & \multirow{3}{*}{ Diet 4} & \multirow{3}{*}{ SEM } & \multicolumn{3}{|c|}{ Probability } \\
\hline & & & & & & \multirow{2}{*}{$\begin{array}{l}\text { main } \\
\text { effect }\end{array}$} & \multicolumn{2}{|c|}{ contrasts } \\
\hline & & & & & & & linear & quadratic \\
\hline Lysine & $0.786^{b c}$ & $0.822^{\mathrm{a}}$ & $0.814^{\mathrm{ab}}$ & $0.756^{c}$ & 0.010 & 0.004 & 0.052 & 0.001 \\
\hline Threonine & $0.805^{\mathrm{ab}}$ & $0.826^{a}$ & $0.796^{b}$ & $0.745^{c}$ & 0.008 & $<0.001$ & $<0.001$ & 0.002 \\
\hline Histidine & $0.742^{\mathrm{a}}$ & $0.764^{a}$ & $0.731^{\mathrm{a}}$ & $0.675^{b}$ & 0.011 & 0.002 & 0.001 & 0.007 \\
\hline Leucine & $0.863^{\mathrm{a}}$ & $0.877^{a}$ & $0.862^{\mathrm{a}}$ & $0.821^{b}$ & 0.007 & 0.001 & 0.001 & 0.003 \\
\hline Isoleucine & $0.830^{\mathrm{a}}$ & $0.851^{a}$ & $0.825^{\mathrm{a}}$ & $0.762^{b}$ & 0.010 & 0.001 & 0.001 & 0.002 \\
\hline Phenylalanine & $0.873^{a}$ & $0.885^{a}$ & $0.869^{a}$ & $0.835^{b}$ & 0.005 & $<0.001$ & $<0.001$ & 0.002 \\
\hline Arginine & $0.916^{\mathrm{a}}$ & $0.919^{a}$ & $0.898^{\mathrm{a}}$ & $0.861^{b}$ & 0.007 & 0.001 & $<0.001$ & 0.016 \\
\hline Valine & $0.814^{\mathrm{a}}$ & $0.835^{a}$ & $0.809^{a}$ & $0.761^{b}$ & 0.011 & 0.007 & 0.005 & 0.013 \\
\hline Glycine & 0.461 & 0.418 & 0.489 & 0.515 & 0.027 & 0.143 & 0.089 & 0.235 \\
\hline Aspartic acid & $0.845^{\mathrm{b}}$ & $0.867^{a}$ & $0.843^{b}$ & $0.804^{c}$ & 0.007 & 0.001 & 0.001 & 0.002 \\
\hline Serine & $0.848^{\mathrm{ab}}$ & $0.859^{a}$ & $0.836^{b}$ & $0.804^{c}$ & 0.006 & 0.001 & $<0.001$ & 0.008 \\
\hline Glutamic acid & $0.898^{\mathrm{ab}}$ & $0.908^{a}$ & $0.890^{b}$ & $0.855^{c}$ & 0.005 & $<0.001$ & $<0.001$ & 0.001 \\
\hline Alanine & $0.793^{b c}$ & $0.827^{a}$ & $0.813^{a b}$ & $0.770^{c}$ & 0.010 & 0.015 & 0.097 & 0.004 \\
\hline Tyrosine & $0.840^{\mathrm{a}}$ & $0.849^{a}$ & $0.839^{a}$ & $0.808^{b}$ & 0.008 & 0.028 & 0.018 & 0.034 \\
\hline Proline & $0.858^{a}$ & $0.840^{\mathrm{a}}$ & $0.841^{a}$ & $0.778^{b}$ & 0.011 & 0.003 & 0.001 & 0.075 \\
\hline
\end{tabular}

means within a row with different superscript $(a-c)$ differ significantly, $P<0.05$ 
of TRLM into the diets, whereas the apparent digestibility of the remaining 13 AA first increased up to $20 \mathrm{~g} \cdot \mathrm{kg}^{-1}$ TRLM, and subsequently decreased. Moreover, there were no significant differences between the diets containing $0 \mathrm{~g} \cdot \mathrm{kg}^{-1}, 20 \mathrm{~g} \cdot \mathrm{kg}^{-1}$, or $40 \mathrm{~g} \cdot \mathrm{kg}^{-1}$ TRLM in the apparent digestibilities of histidine, leucine, isoleucine, phenylalanine, arginine, valine, tyrosine, and proline, but they were significantly higher $(P<0.05)$ than in the diet containing $60 \mathrm{~g} \cdot \mathrm{kg}^{-1}$ TRLM. In addition, the apparent digestibility of aspartic acid was higher $(P<0.05)$ in the diet containing $20 \mathrm{~g} \cdot \mathrm{kg}^{-1}$ TRLM compared with the diets containing $0 \mathrm{~g} \cdot \mathrm{kg}^{-1}$ and $40 \mathrm{~g} \cdot \mathrm{kg}^{-1}$ TRLM; in both of these diets, the apparent digestibility of this amino acid was higher $(P<0.05)$ than in the diet containing $60 \mathrm{~g} \cdot \mathrm{kg}^{-1}$ TRLM.

\section{Discussion}

Egg mass and egg weight were both higher when feeding $40 \mathrm{~g} \cdot \mathrm{kg}^{-1}$ TRLM to laying hens than the other three diets. Yang et al. (1992) found that substituting from $30 \mathrm{~g} \cdot \mathrm{kg}^{-1}$ to $50 \mathrm{~g} \cdot \mathrm{kg}^{-1}$ black locust leaf meal for wheat bran would enhance egg mass and egg weight. Dancea et al. (2005) also found that combined feed containing $63 \mathrm{~g} \cdot \mathrm{kg}^{-1}$ black locust leaf meal positively influenced egg production and egg weight in layers. Furthermore, there were no significant differences between the diets containing 40 to $50 \mathrm{~g} \cdot \mathrm{kg}^{-1}$ black locust leaf meal and lucerne in egg weight, body weight and mortality (Takada et al., 1980; Wu and Han, 1985).

No significant effect of TRLM supplementation on laying rate, feed intake, feed conversion, or mortality rate was found throughout the experimental period. Moreover, egg quality parameters such as eggshell colour, eggshell strength, eggshell thickness, albumen height, Haugh units and yolk colour were not affected by the diet. These findings showed that the inclusion of TRLM did not constitute any physically visible health hazards. Ran et al. (1996) reported, however, that feeding $30 \mathrm{~g} \cdot \mathrm{kg}^{-1}$ to $50 \mathrm{~g} \cdot \mathrm{kg}^{-1}$ black locust leaf meal to 40 weeks age of Roman hens increased laying rate, feed conversion rate, and economic benefits. Wang and Yin (1992) found that substituting $50 \mathrm{~g} \cdot \mathrm{kg}^{-1}$ black locust leaf meal for wheat bran could enhance the laying rate by $9.76 \%$. Dancea et al. (2005) also reported that combined feed containing $63 \mathrm{~g} \cdot \mathrm{kg}^{-1}$ black locust leaf meal positively influenced health and egg yolk colour in layers, and their metabolism was also much more uniform. Paterson et al. (2000) and Yang et al. (1992) both suggested that the use of high-protein tree fodder in poultry rations might reduce feeding costs and provide sufficient pigment to make the eggs more attractive and nutritious.

The apparent digestibility of $\mathrm{CP}, \mathrm{EE}, \mathrm{GE}$, ADF and 13 AA (except glycine and proline) first increased with up to $20 \mathrm{~g} \cdot \mathrm{kg}^{-1}$ TRLM and then decreased with increasing TRLM. To the authors' knowledge, no comparable published data on the influence of black locust leaf meal on nutrient and AA digestibility of a laying hen diet are available. Cheeke et al. (1983) did, however, find pronounced growth depressing effect of black locust at a high $\left(200 \mathrm{~g} \cdot \mathrm{kg}^{-1}\right)$ level in broiler chicken diets. Tannins and other phenolics are the likely cause of the low nutrient availability (Cheeke, 1992). Apart from tannins, D'Mello (1992) postulated that the poor digestibility and availability of nutrients resulting from the presence of a component with a high fibre content could explain the poor performance of poultry fed on leguminous leaf meals. These results suggest that TRLM might depress the digestibility of both protein and organic matter in poultry, and may only be useful as a feed supplement in laying hens at low levels of supplementation, particularly at inclusions not exceeding $60 \mathrm{~g} \cdot \mathrm{kg}^{-1}$. Although tetraploid Robinia pseudoacacia has tannins and fibre that reduce nutrient digestibility, wildlife and livestock will consume it, especially as a source of nutrients for a ruminant species well adapted to highly fibrous ingredients.

\section{Conclusions}

Tetraploid Robinia pseudoacacia leaf meal (TRLM) shows promise as an alternative diet for laying hens at $20 \mathrm{~g} \cdot \mathrm{kg}^{-1}-40 \mathrm{~g} \cdot \mathrm{kg}^{-1}$ without any adverse effects on performance, egg quality, apparent nutrient and amino acid (AA) digestibilities. Although $20 \mathrm{~g} \cdot \mathrm{kg}^{-1}$ TRLM addition to diets had no significant effect on hen performance or egg quality, apparent nutrient and AA digestibilities were improved.

\section{Acknowledgements}

The authors thank Harry Wu and Miloš Ivković of CSIRO Plant Industry in Australia for revising this manuscript. We also acknowledge financial support from the following programmes: Forestry Public Benefit Research Programme (No.201004008), National Key Project of Scientific and Technical Supporting Project (No. 2012BAD01B0601), National High-tech R\&D Programme (863 No. 2007AA100105). 


\section{References}

Ainalis A.B., Tsiouvaras C.N., 1998. Forage production of woody fodder species and herbaceous vegetation in a silvopastoral system in northern Greece. Agroforest. Syst. 42, 1-11

AOAC, 2000. Association of Official Analytical Chemists, Official Methods of Analysis. $17^{\text {th }}$ Edition. Gaithersburg, MD

Barrett R.P., Mebrahtu T., Hanover J.W., 1990. Black locust: A multi-purpose tree species for temperate climates. In: J. Janick, J.E. Simon (Editors). Advances in New Crops. Proceedings of the First Symposium NEW CROPS: Research, Development, Economics. Portland, Oregon, pp. 278-283

Burner D.M., Pote D.H., Ares A., 2005. Management effects on biomass and foliar nutritive value of Robinia pseudoacacia and Gleditsia triacanthos f. inermis in Arkansas, USA. Agroforest. Syst. 65, 207-214

Cheeke P.R., 1992. Black locust forage as an animal feedstuff. In: J.W. Hanover, K. Miller, S. Plesko (Editors). Proceedings of International Conference on Black Locust: Biology, Culture and Utilization. East Lansing, Michigan (USA), pp. 252-258

Cheeke P.R., Goeger M.P., Arscott G.H., 1983. Utilization of black locust (Robinia pseudoacacia) leaf meal by chicks. Nitrogen Fixing Tree Res. Rep. 1, 44

Dancea Z., Orban C., Macri A., Maria V., Morar Szakacs A., Nueleanu V., 2005. Investigations on the impact of acacia leaves in the feed of laying hens. Bull. USAMV-CN, 62, 614

D'Mello J.P.F., 1992. Nutritional potentialities of fodder trees and fodder shrubs as protein sources in monogastric nutrition. In: A. Speedy, P.L. Pugliese (Editors). Legume Trees and Other Trees as Protein Sources for Livestock. Kuala Lumpur (Malaysia), 102, pp. 115-127

Hammerle J.R., 1969. An engineering appraisal of egg shell strength evaluation techniques. Poultry Sci. 48, 1708-1717

Kim C.S., Lee S.K., 1973. Morphological and cytological characteristics of a spontaneous tetraploid of Robinia pseudoacacia. (Abstract) The Institute of Forest Genetics, Research Report 10, Republic of Korea, pp. 57-65

Li Y., Zhang G.J., Jiang J.Z., 2009. Tetraploid black locust, a promising tree resource for biomass energy and forage. In Vitro Cell. Dev. Biol. - Plant 45, 505-505

Negi S.S., Singh B., Markar H.P.S., 1989. Influence of method of calculation and length of period of rumen fermentation on the effective degradability of dry matter and nitrogen in some tree forages. Anim. Feed Sci. Tech. 26, 309-322
Papanastasis V.P., Platis P.D., Dini-Papanastasi O., 1997. Productivity of deciduous woody and fodder species in relation to air temperature and precipitation in a Mediterranean environment. Agroforest. Syst. 37, 187-198

Paterson R.T., Roothaert R.L., Kiruiro E., 2000. The feeding of leaf meal of Calliandra calothyrsus to laying hens. Trop. Anim. Health Prod. 32, 51-61

Ran Y.E., Zhao Y.F., Wang Q.Y., 1996. A study on the feeding effect of powder of $R$. pseudoacacia leaves on laying hens(in Chinese). Acta Agric. Univ. Jiangxiensis, 18, 363-366

Takada K., Nakazato T., Ono Honda H., Yamane T., 1980. Feeding value of leaf meal of acacia in poultry feed(in Japanese). Jpn. Poultry Sci. 17, 299-305

Unruh Snyder L.J., Luginbuhl J.M., Mueller J.P., Conrad A.P., Turner K.E., 2007. Intake, digestibility and nitrogen utilization of Robinia pseudoacacia foliage fed to growing goat wethers. Small Ruminant Res. 71, 179-193

Van Soest P.J., Robertson J.B., Lewis B.A., 1991. Symposium: carbohydrate methodology, metabolism, and nutritional implications in dairy cattle. Methods for dietary fiber, neutral detergent fiber, and nonstarch pilysaccharides in relation to animal nutrition. J. Dairy Sci. 74, 3583-3597

Wang Z.M., Yin J.M., 1986. Effects of Robinia pseudoacacia leaf meal on laying hens (in Chinese). Hebei Anim. Husbandry Vet. Med. 1, 7-8

Wu C.K., Han Y.W., 1985. Effects of different leguminous herbage powder in diets on laying hens (in Chinese). Heilongjiang Anim. Sci. Vet. Med. 10, 6-7

Yang J.B., Liu Y.G., Xu Z.C., 1992. Effects of Robinia pseudoacacia leaves on laying performance (in Chinese). Chinese J. Anim. Sci. 28(5), 29-30, 50

Zhang G.J., Li Y., Jiang J.Z., Lu C., 2007. Comparative study on value of tetraploidy black locust (Robinia pseudoacacia) leaf meal as a feed (in Chinese). Pratacult. Sci. 24, 26-31

Zhang G.J., Li Y., Li F.P., Xu Z.H., Sun Y.H., 2009. Effects of age of root on biomass and leaf nutrition in tetraploid Robinia pseudoacacia (in Chinese). J. Beijing Forest. Univ. 31, 37-41

Zhang G.J., Li Y., Xu Z.H., Jiang J.Z., Han F.B., Liu J.H., 2012. The chemical composition and ruminal degradation of the protein and fibre of tetraploid Robinia pseudoacacia harvested at different growth stages. J. Anim. Feed Sci. 21, 177-187 